\author{
PAWEŁ KŁUSEK \\ Uniwersytet Wrocławski \\ e-mail: pawel.klusek@uwr.edu.pl
}

\title{
Nadawanie uprawnień zawodowych w zakresie szacowania nieruchomości
}

\section{Wstęp}

Uprawnienia w zakresie szacowania nieruchomości przysługują osobom fizycznym wykonującym zawód rzeczoznawcy majątkowego. Profesja ta została uregulowana w Ustawie z dnia 21 sierpnia 1997 r. o gospodarce nieruchomościa$\mathrm{mi}^{1}$. Zgodnie $\mathrm{z}$ art. 191 ust. 1 u.g.n. uprawnienia w zakresie szacowania nieruchomości nadaje minister właściwy do spraw budownictwa, planowania i zagospodarowania przestrzennego oraz mieszkalnictwa osobom, które spełniły wymogi określone w art. 177 u.g.n. Oznacza to, że do wykonywania zawodu rzeczoznawcy majątkowego potrzebne są szczególne kwalifikacje, wymienione w ustawie o gospodarce nieruchomościami. W związku z tym należy się zastanowić, jaki status prawny ma zawód rzeczoznawcy majątkowego. $Z$ jednej strony można go bowiem uznać za wolny zawód, a z drugiej — za zawód zaufania publicznego. Jeżeli profesję rzeczoznawcy majątkowego zakwalifikujemy do tej drugiej kategorii, wówczas powstanie pytanie, kto powinien nadawać uprawnienia zawodowe w zakresie szacowania nieruchomości.

Celem niniejszego artykułu jest ustalenie statusu prawnego zawodu rzeczoznawcy majątkowego i ocena regulacji prawnej przyznającej kompetencje do nadawania uprawnień zawodowych ministrowi, o którym mowa w art. 191 u.g.n. Aby zrealizować powyższe cele, $w$ pracy zostanie zastosowana metoda formalno-dogmatyczna, polegająca na analizie obowiązujących tekstów prawnych.

${ }^{1}$ Ustawa z dnia 21 sierpnia 1997 r. o gospodarce nieruchomościami (tekst jedn. Dz.U. z 2016 r. poz. 2147; dalej: u.g.n.). 


\section{Status prawny zawodu rzeczoznawcy majątkowego}

Jak już zasygnalizowano, zawód rzeczoznawcy majątkowego uregulowano w ustawie o gospodarce nieruchomościami z 1997 r. Jednak profesja ta była wykonywana w Polsce jeszcze przed uchwaleniem wspomnianej ustawy. Szacowaniem wartości nieruchomości zajmowano się już w okresie międzywojennym, kiedy usługi w tym zakresie świadczyli specjaliści do spraw budownictwa ${ }^{2}$. W późniejszym okresie obowiązywała Ustawa z dnia 29 kwietnia 1985 r. o gospodarce gruntami i wywłaszczaniu nieruchomości ${ }^{3}$, która stanowiła, że biegli wpisani na listę wojewódzką i inne uprawnione osoby (biegli sądowi) mają prawo do określania wartości gruntów ${ }^{4}$. Następnie możemy wskazać Ustawę z dnia 17 maja 1989 r. - Prawo geodezyjne i kartograficzne ${ }^{5}$, która do samodzielnych funkcji w dziedzinie geodezji i kartografii zaliczała czynności polegające na szacowaniu nieruchomości. Pomimo istnienia wcześniejszych regulacji należy zauważyć, że dopiero w ustawie o gospodarce nieruchomościami w sposób kompleksowy unormowano problematykę wykonywania zawodu rzeczoznawcy majątkowego.

Jeżeli chodzi o status prawny tej profesji, to w pierwszej kolejności możemy stwierdzić, że rzeczoznawca majątkowy jest wolnym zawodem. Przesądza o tym treść art. $86 \S 1$ k.s.h. ${ }^{6}$ w zw. z art. 88 k.s.h. Pierwszy z tych przepisów stanowi, że spółkę partnerską tworzą wspólnicy w celu wykonywania wolnego zawodu ${ }^{7}$. Natomiast zgodnie $\mathrm{z}$ drugim $\mathrm{z}$ nich partnerami w spółce partnerskiej mogą być przedstawiciele wymienionych enumeratywnie zawodów, do których zaliczono także rzeczoznawców majątkowych ${ }^{8}$.

Co ciekawe, ustawodawca nie wyjaśnia, jak należy rozumieć pojęcie „wolny zawód”. Wymienia jednak profesje, które utożsamia z tym terminem, dzięki cze-

${ }^{2}$ E. Bończak-Kucharczyk, Ustawa o gospodarcze nieruchomościami. Komentarz, Warszawa 2014, s. 1004.

3 Tekst jedn. Dz.U. z 1991 r. Nr 30, poz. 127 ze zm.

4 Ustawa o gospodarce nieruchomościami. Komentarz, red. P. Czechowski et al., Warszawa 2015, s. 782.

5 Dz.U. z 1989 r. Nr 30, poz. 163.

${ }^{6}$ Ustawa z dnia 15 września 2000 r. — Kodeks spółek handlowych (tekst jedn. Dz.U. z 2000 r. Nr 94, poz. 1037; dalej: k.s.h.).

7 Art. 86 § 1 k.s.h.: ,[s]półką partnerską jest spółka osobowa, utworzona przez wspólników (partnerów) w celu wykonywania wolnego zawodu w spółce prowadzącej przedsiębiorstwo pod własną firmą".

8 Art. 88 k.s.h.: ,[p]artnerami w spółce mogą być osoby uprawnione do wykonywania następujących zawodów: adwokata, aptekarza, architekta, inżyniera budownictwa, biegłego rewidenta, brokera ubezpieczeniowego, doradcy podatkowego, maklera papierów wartościowych, doradcy inwestycyjnego, księgowego, lekarza, lekarza dentysty, lekarza weterynarii, notariusza, pielęgniarki, położnej, radcy prawnego, rzecznika patentowego, rzeczoznawcy majątkowego i thumacza przysięgłego". 
mu w doktrynie podjęto próby ustalenia konstytutywnych cech wolnego zawodu. Wydaje się, że spośród wszystkich zaproponowanych definicji najszersze uznanie znalazła ta sformułowana przez Krystnę Wojtczak, która opisała wolny zawód jako

osobiste i samodzielne wykonywanie wewnętrznie spójnego zespołu czynności o charakterze intelektualnym, wymagających wysokich kwalifikacji (wiedzy i praktyki), systematycznie, w zamian za honorarium bezinteresownie ustalone, służące zapewnieniu świadczeń i usług klientom oraz ochronie innych wartości interesu ogólnego, zgodnie z obowiązującymi normami prawnymi, zasadami etycznymi i deontologicznymi ${ }^{9}$.

Podobne cechy wolnego zawodu wymienia Jerzy Jacyszyn, który zalicza do nich: 1) kwalifikowane, szczególne wykształcenie; 2) specyficzne zasady wykonywania zawodu; 3) niezależność zawodową; 4) etos i misję wykonywania zawodu; 5) sposób i stan zorganizowania; 6) etykę zawodową; 7) charakter wynagrodzenia odmienny od typowej zapłaty; 8) tajemnicę zawodową; 9) specyficzną odpowiedzialność cywilną, a także porządkową czy też korporacyjną; 10) obowiązkową przynależność do samorządu zawodowego ${ }^{10}$.

Analizując wymienione cechy wolnych zawodów, należy przyjąć, że rzeczoznawca majątkowy z całą pewnością zalicza się do tej szczególnej kategorii zawodów. Świadczą o tym przepisy działu V ustawy o gospodarce nieruchomościami, które regulują istotne cechy tej profesji. Przykładowo możemy tu wskazać art. 177 ust. 1 u.g.n., nakładający na osoby starające się o nadanie uprawnień w zakresie szacowania nieruchomości obowiązek posiadania wyższego wykształcenia, ukończenia studiów podyplomowych w zakresie wyceny nieruchomości czy odbycie co najmniej sześciomiesięcznej praktyki zawodowej ${ }^{11}$.

We wstępie zaznaczono, że trzeba także rozważyć zakwalifikowanie profesji rzeczoznawcy majątkowego do kategorii zawodów zaufania publicznego. Pojęcie takiej grupy zawodów zostało wprowadzone do polskiego porządku prawnego przez Konstytucję Rzeczypospolitej Polskiej z dnia 2 kwietnia 1997 r. W art. 17 ust. 1 Konstytucji ustrojodawca przewidział bowiem, że:

W drodze ustawy można tworzyć samorządy zawodowe, reprezentujące osoby wykonujące zawody zaufania publicznego i sprawujące pieczę nad należytym wykonywaniem tych zawodów w granicach interesu publicznego i dla jego ochrony.

Jak widać, w tym przypadku prawodawca również nie wyjaśnił, jak należy rozumieć pojęcie „zawodu zaufania publicznego”. Przewidział natomiast, że dla tego typu profesji ustawodawca może tworzyć samorządy zawodowe, co w praktyce może prowadzić do sporów odnośnie do tego, które grupy zawodowe powinny otrzymać przywilej posiadania własnego samorządu. Aby rozstrzygnąć

9 K. Wojtczak, Zawód i jego prawna reglamentacja. Studium z zakresu materialnego prawa administracyjnego, Poznań 1999, s. 112.

10 J. Jacyszyn, Wykonywanie wolnych zawodów w Polsce, Warszawa 2004, s. 51.

11 Szerzej na ten temat zob. P. Kłusek, Status prawny zawodu rzeczoznawcy majatkowego, „Problemy Rynku Nieruchomości” 2015, nr 2, s. 54-55. 
ten problem i odpowiedzieć na pytanie, czy rzeczoznawcy majątkowi powinni posiadać własny samorząd zawodowy, trzeba najpierw ustalić, jakie cechy konstytutywne ma zawód zaufania publicznego.

Z pomocą przychodzi nam doktryna i orzecznictwo, w których podjęto próby zdefiniowania zawodu zaufania publicznego. Przykładowo możemy tu przytoczyć pogląd Jerzego Hausnera i Dagmira Długosza, którzy przyjmują, że niezbędnymi elementami pojęcia zawodów, o których mowa w art. 17 ust. 1 Konstytucji, są: 1) posiadanie newralgicznych informacji o klientach i uznawanie ich za tajemnicę zawodową; 2) posiadanie immunitetu zwalniającego z odpowiedzialności za nieujawnienie tych informacji; 3) niepodleganie regułom hierarchii urzędniczej; 4) występowanie sformalizowanej deontologii zawodowej; 5) konieczność spełniania bardzo wysokich wymogów etycznych, nienarzucanych z zewnątrz, tradycyjnie kształtowanych przez samo środowisko korporacji zawodowej; 6) wyraźne oddzielenie samorządu tych zawodów od samorządu gospodarczego ${ }^{12}$.

Podobne cechy wymienia Hubert Izdebski, który do konstytutywnych cech zawodu zaufania publicznego zalicza: regulowany charakter, zdolność do autoregulacji i samoregulacji środowiskowej, występowanie określonych standardów postępowania, posiadanie własnego kodeksu etycznego oraz rzeczywiste wykonywanie zawodu w praktyce ${ }^{13}$.

$\mathrm{Na}$ temat istoty zawodu zaufania publicznego wiele razy wypowiedział się także Trybunał Konstytucyjny ${ }^{14}$, który w wyroku z dnia 24 marca 2015 r. podsumował dotychczasowe orzecznictwo w tym zakresie i uwzględniając poglądy doktryny, wyróżnił sześć konstytutywnych cech profesji, o których mowa w art. 17 ust. 1 Konstytucji ${ }^{15}$. Biorąc pod uwagę, iż orzeczenia Trybunału Konstytucyjnego mają moc powszechnie obowiązującą i że przywołane orzeczenie zawiera syntezę dotychczasowych poglądów, wydaje się, że na jego podstawie można przeprowadzić analizę cech zawodu rzeczoznawcy majątkowego i ustalić, czy kwalifikuje się on do grupy zawodów zaufania publicznego.

Pierwszą cechą wyróżnioną przez Trybunał jest „konieczność zapewnienia prawidłowego i zgodnego $\mathrm{z}$ interesem publicznym wykonywania zawodu, ze względu na znaczenie, jakie dana dziedzina aktywności zawodowej ma w społe-

12 J. Hausner, D. Długosz, Tezy w sprawie zawodów zaufania publicznego, [w:] Zawody zaufania publicznego a interes publiczny — korporacyjna reglamentacja versus wolność wykonywania zawodu. Materiaty z konferencji zorganizowanej przez Komisję Polityki Spotecznej i Zdrowia Senatu RP przy wspótudziale Ministerstwa Pracy i Polityki Spotecznej pod patronatem Marszałka Senatu RP Longina Pastusiaka, 8 kwietnia 2002 r., oprac. S. Legat, M. Lipińska, Warszawa 2002, s. $119-120$.

${ }^{13}$ H. Izdebski, Sprawowanie pieczy nad należytym wykonywaniem zawodu przez samorzady zawodowe, [w:] Zawody zaufania publicznego..., s. 34.

14 Wyrok TK z dnia 7 marca 2012 r., sygn. K 3/10, OTK ZU nr 3/A/2012, poz. 25; wyrok TK z dnia 26 marca 2008 r., sygn. K 4/07, OTK ZU nr 2/A/2008, poz. 28; wyrok TK z dnia 2 lipca 2007 r., sygn. K 41/05, OTK ZU nr 7/A/2007, poz. $72 \mathrm{i}$ in.

15 Wyrok TK z dnia 24 marca 2015 r., sygn. K 19/14, OTK ZU nr 33/3/A/2015, poz. 32. 
czeństwie" ${ }^{16}$. Oznacza to, że czynności zawodowe wykonywane przez przedstawiciela danej profesji muszą służyć zabezpieczeniu podstawowych dóbr i wartości kluczowych dla prawidłowego funkcjonowania społeczeństwa. Ustalenie, które dobra i wartości będą miały tak fundamentalny charakter, wydaje się trudnym zadaniem, albowiem jest to kwestia ocenna i można by tu tworzyć różne katalogi przy uwzględnianiu rozmaitych kryteriów.

Wydaje się jednak, że dla ustawodawcy głównym wyznacznikiem powinno być kryterium prawne, co implikuje poszukiwanie takich dóbr i wartości w akcie prawnym najwyższej rangi. Powstaje zatem pytanie, czy czynności zawodowe rzeczoznawcy majątkowego zabezpieczają wartości chronione przez Konstytucję. Odpowiedź na to pytanie może być twierdząca z uwagi na znaczenie czynności polegających na szacowaniu wartości nieruchomości dla zabezpieczenia interesów majątkowych społeczeństwa. Konstytucja podkreśla bowiem znaczenie własności prywatnej, wymieniając ją jako jedną z podstaw społecznej gospodarki rynkowej ${ }^{17}$. Co więcej, art. 64 Konstytucji stanowi wprost, że każdy ma prawo do własności, innych praw majątkowych oraz prawo dziedziczenia, a także przesądza o tym, że prawa te podlegają równej dla wszystkich ochronie prawnej ${ }^{18}$. Dlatego też rzeczoznawca musi dokładać wszelkiej staranności, aby w sposób prawidłowy szacować wartość wycenianych nieruchomości, które często stanowią znaczą część naszego majątku. Należy pamiętać, że od wyceny może zależeć m.in. ocena zdolności kredytowej, wysokość zobowiązania podatkowego ${ }^{19}$ lub opłaty za użytkowanie wieczyste ${ }^{20}$ czy wysokość odszkodowania w razie powstania szkód na nieruchomości. Widać zatem, że prawidłowe wykonywanie czynności zawodowych przez rzeczoznawców majątkowych zabezpiecza jedną z podstawowych wartości konstytucyjnych, jaką jest prawo własności i prawo do innych praw majątkowych.

Drugą cechą wskazaną przez Trybunał jest udzielanie świadczeń i wchodzenie przez przedstawicieli zawodów zaufania publicznego w kontakty z osobami fizycznymi w razie wystąpienia potencjalnego lub realnego zagrożenia dóbr

16 Ibidem.

17 Art. 20 Konstytucji: ,[s]połeczna gospodarka rynkowa oparta na wolności działalności gospodarczej, własności prywatnej oraz solidarności, dialogu i współpracy partnerów społecznych stanowi podstawę ustroju gospodarczego Rzeczypospolitej Polskiej”.

18 Art. 64 Konstytucji: „1. Każdy ma prawo do własności, innych praw majątkowych oraz prawo dziedziczenia. 2. Własność, inne prawa majątkowe oraz prawo dziedziczenia podlegają równej dla wszystkich ochronie prawnej. 3. Własność może być ograniczona tylko w drodze ustawy i tylko w zakresie, w jakim nie narusza ona istoty prawa własności”.

19 A. Bartosiewicz, R. Kubacki, Pit. Komentarz, wyd. 5, Warszawa 2015, komentarz do art. 22g, pkt 30, s. 732-733.

${ }^{20}$ Ustawa o gospodarce nieruchomościami. Komentarz, red. P. Czechowski, Warszawa 2015, komentarz do art. 77, s. 333; A. Kwartnik-Pruc, A. Trembecka, Wybrane problemy aktualizacji opłat rocznych z tytulu użtkowania wieczystego na przyktadzie miasta Krakowa, „Zeszyty Naukowe Uniwersytetu Szczecińskiego. Studia i Prace Wydziału Nauk Ekonomicznych i Zarządzania” 1, 2014, nr 36, s. 325. 
o szczególnym charakterze. Także tutaj można by argumentować, że rzeczoznawcy majątkowi spełniają to kryterium, ponieważ często świadczą usługi na rzecz osób fizycznych, pomagając im zabezpieczyć ich interesy majątkowe. Usługi te mogą być świadczone w sposób bezpośredni (np. wyceny dla celów procesowych $)^{21}$ lub pośredni (np. wycena w celu ustalenia wysokości odszkodowania za wywłaszczenie) $)^{22}$.

Trzecią cechą, o której wspomina Trybunał, jest staranność i dbałość przedstawicieli zawodów zaufania publicznego o interesy osób korzystających z ich usług, troska o ich osobiste potrzeby oraz zapewnienie ochrony gwarantowanych przez Konstytucję praw podmiotowych jednostek. W tym miejscu należy się zastanowić, czy rzeczoznawca majątkowy całkowicie spełnia to kryterium. Wątpliwości może budzić fakt, iż zgodnie z art. 175 ust. 1 u.g.n. rzeczoznawca majątkowy zobowiązany jest kierować się przy wycenie zasadą bezstronności. Oznacza to, że nie może wykonywać swoich czynności w taki sposób, aby wynikiem jego pracy było ustalenie wartości nieruchomości korzystnej dla klienta. Z drugiej strony, to właśnie obowiązek zachowania obiektywizmu i bezstronności przy szacowaniu wartości nieruchomości może być gwarancją zabezpieczenia interesów i potrzeb klienta ${ }^{23}$. Co więcej, nałożenie na rzeczoznawcę obowiązku zachowania bezstronności może świadczyć o szczególnym charakterze tej profe$\mathrm{sji}^{24}$. Podobnie wypowiedział się Wojewódzki Sąd Administracyjny w Warszawie, który orzekł, że

pozycja prawna rzeczoznawcy majątkowego, którego ustawa o gospodarce nieruchomościami, standardy zawodowe oraz kodeks etyki obciążają bardzo poważnymi obowiązkami, jest w istocie rzeczy zbliżona do statusu osoby zaufania publicznego... ${ }^{25}$

Czwartą cechą zawodu zaufania publicznego jest wymóg posiadania szczególnych kwalifikacji, niezbędnych do jego wykonywania. Oznacza to, że konstytucyjna wolność pracy wyrażona w art. 65 Konstytucji może być ograniczona

21 Rzeczoznawca może świadczyć usługi bezpośrednio dla klienta, który musi udowodnić w pozwie wartość nieruchomości będącej przedmiotem sporu. Zob. K. Badowska-Zygmuntowicz, Specyfika operatu szacunkowego jako dowodu w postępowaniu cywilnym, „Zeszyty Naukowe Państwowej Wyższej Szkoły Zawodowej im. Witelona w Legnicy” 2016, nr 18 (1), s. 8.

22 Rzeczoznawca jako biegły z zakresu szacowania nieruchomości powoływany jest przez właściwy organ do określenia wartości nieruchomości mającej być przedmiotem wywłaszczenia. Zob. E. Bończak-Kucharczyk, Ustawa o gospodarce nieruchomościami. Komentarz aktualizowany, Warszawa 2017, komentarz do art. 130, pkt 1, s. 926-930.

23 Przykładowo chodzi tu o sytuację, gdy rzeczoznawca majątkowy wykonuje zlecenie banku lub ubezpieczyciela, a od jego wyceny zależą interesy majątkowe osoby fizycznej, której mienie jest przedmiotem wyceny. Może to być również ewentualność, kiedy klientowi faktycznie zależy na uzyskaniu rzetelnej wyceny, albowiem od jej wyniku nie jest uzależnione otrzymanie dodatkowej korzyści majątkowej, np. w postaci wyższego kredytu lub odszkodowania.

${ }^{24}$ E. Bończak-Kucharczyk, op. cit., komentarz do art. 175, pkt 1, s. 1163-1164.

25 Wyrok WSA w Warszawie z dnia 29 sierpnia 2009 r., syng. I SA/Wa 873/07, http://orzeczenia.nsa.gov.pl/doc/26772DD783 (dostęp: 10.11.2017). 
w przypadku zawodów zaufania publicznego, ze względu na konieczność posiadania odpowiednich kwalifikacji ${ }^{26}$. Dotyczy to również zawodu rzeczoznawcy majątkowego, którego przedstawiciel musi spełniać wymogi określone w art. 177 ust. 1 u.g.n.; na przykładzie tego przepisu możemy zauważyć, że rzeczoznawca musi posiadać zarówno kwalifikacje teoretyczne (ukończenie studiów wyższych, ukończenie studiów podyplomowych w zakresie wyceny nieruchomości), praktyczne (zaliczenie co najmniej sześciomiesięcznej praktyki zawodowej), jak i osobiste (posiadanie pełnej zdolności do czynności prawnych, brak karalności za określone w ustawie przestępstwa). Dodatkowo osoba mająca otrzymać uprawnienia zawodowe rzeczoznawcy majątkowego musi przejść z wynikiem pozytywnym postępowanie kwalifikacyjne, którego częścią jest złożenie egzaminu sprawdzającego posiadanie wymaganych kwalifikacji zawodowych. Należy też zauważyć, że rzeczoznawca majątkowy, na mocy art. 175 ust. 2 u.g.n., zobowiązany jest do stałego doskonalenia swoich kwalifikacji zawodowych.

Piątą cechą wskazaną przez Trybunał Konstytucyjny jest „,pozyskiwanie informacji osobistych i dotyczących życia prywatnego osób korzystających z usług przedstawicieli zawodu zaufania publicznego"27. Podkreślono również, że informacje te stanowią tajemnicę zawodową, z której można zostać zwolnionym wyłącznie na podstawie przepisów Kodeksu postępowania karnego. Także tutaj nie ma wątpliwości, że zawód rzeczoznawcy majątkowego ma tę cechę zawodu zaufania publicznego, albowiem obowiązek zachowania tajemnicy zawodowej nakłada na niego art. 175 ust. 3 u.g.n. ${ }^{28}$ Warto zaznaczyć, że tajemnicą objęte są nie tylko informacje dotyczące wycenianej nieruchomości, lecz także informacje o nieruchomościach podobnych. Tajemnica obejmuje w szczególności dane osobowe oraz informacje mogące prowadzić do ich ujawnienia (np. numer księgi wieczystej). Naruszenie przez rzeczoznawcę majątkowego tajemnicy zawodowej może skutkować odpowiedzialnością zawodową przewidzianą w ustawie o gospodarce nieruchomościami, odpowiedzialnością karną lub odpowiedzialnością cywilną29.

Ostatnią konstytutywną cechą zawodu zaufania publicznego wymienioną przez Trybunał Konstytucyjny jest względna samodzielność przy wykonywaniu zawodu. W przypadku zawodu rzeczoznawcy majątkowego samodzielność wy-

26 Konstytucja Rzeczypospolitej Polskiej. Komentarz, red. M. Haczkowska, Warszawa 2014, komentarz do art. 65, pkt 4, s. 119-120.

27 Wyrok TK z dnia 24 marca 2015 r.

28 Art. 175 ust. 3 u.g.n.: ,[i]nformacje uzyskane przez rzeczoznawcę majątkowego w związku z wykonywaniem zawodu stanowią tajemnicę zawodową. W szczególności informacje uzyskane w toku wykonywania czynności zawodowych nie mogą być przekazywane osobom trzecim, chyba że odrębne przepisy stanowią inaczej lub w przypadkach, o których mowa w art. 157, art. 194, art. 195 i art. 195a".

29 A. Gryszczyńska, Tajemnica rzeczoznawcy majątkowego, „Monitor Prawniczy”2015, nr 22, http://czasopisma.beck.pl/monitor-prawniczy/artykul/tajemnica-rzeczoznawcy-majatkowego/ (dostęp: 15.08.2017). 
konywania czynności zawodowych wynika z ustawy o gospodarce nieruchomościami. Ustawodawca przewidział bowiem, że rzeczoznawstwo majątkowe jest działalnością zawodową wykonywaną przez rzeczoznawców, a więc osoby, które posiadają odpowiednie uprawnienia zawodowe (art. 174 ust. 1-2 u.g.n.). Co więcej, art. 174 ust. 6 u.g.n. stanowi, że prowadzenie działalności w zakresie szacowania nieruchomości na terytorium Rzeczypospolitej Polskiej jest możliwe tylko wtedy, gdy czynności z zakresu szacowania będą wykonywane przez rzeczoznawców majątkowych. Należy też podkreślić, że rzeczoznawca majątkowy, wykonując swoje czynności zawodowe, musi kierować się przepisami prawa, standardami zawodowymi, zasadami etyki i zasadą bezstronności, a nie wytycznymi zleceniodawcy. Taka regulacja stanowi gwarancję samodzielnego wykonywania zawodu przez rzeczoznawcę majątkowego.

Biorąc pod uwagę wymienione cechy zawodu zaufania publicznego, możemy dojść do wniosku, że zawód rzeczoznawcy majątkowego mógłby zostać zakwalifikowany do profesji, o których mowa w art. 17 ust. 1 Konstytucji. Wątpliwości budzi jednak fakt, że ustawodawca w dalszym ciągu nie skorzystał ze swojej kompetencji i nie ustanowił samorządu zawodowego rzeczoznawców majątkowych ${ }^{30}$. Utworzenie takiej korporacji w formie ustawy przesądziłoby ostatecznie o statusie prawnym zawodu rzeczoznawcy majątkowego i umożliwiłoby przeniesienie na samorząd zawodowy kompetencji, które obecnie przysługują władzy wykonawczej - w tym także kompetencji do nadawania uprawnień zawodowych.

\section{Podmiot nadający uprawnienia w zakresie szacowania nieruchomości}

Poczynione wyżej ustalenia odnośnie do statusu prawnego zawodu rzeczoznawcy majątkowego mogą być przydatne do oceny dotychczasowych przepisów regulujących nadawanie uprawnień zawodowych $\mathrm{w}$ zakresie szacowania nieruchomości. W aktualnym stanie prawnym kompetencja ta przysługuje ministrowi właściwemu do spraw budownictwa, planowania i zagospodarowania przestrzennego oraz mieszkalnictwa. Należy się jednak zastanowić, czy z uwagi na szczególny status zawodu rzeczoznawcy majątkowego ustawodawca nie powinien utworzyć samorządu zawodowego, który przejąłby kompetencję do nadawania uprawnień zawodowych w zakresie szacowania nieruchomości.

30 Próbę uchwalenia ustawy powołującej do życia samorząd zawodowy rzeczoznawców majątkowych podjęto w 2011 r. Zob. J. Jasiński, Samorząd Zawodowy Rzeczoznawców Majątkowych?, http://czasopisma.beck.pl/nieruchomosci/artykul/samorzad-zawodowy-rzeczoznawcow-majatkowych/ (dostęp: 15.08.2017). 
Obecnie ministrem właściwym do spraw budownictwa, planowania i zagospodarowania przestrzennego oraz mieszkalnictwa jest minister infrastruktury i budownictwa ${ }^{31}$. Jest on naczelnym organem administracji rządowej i pełni podwójną funkcję: członka kolegialnego organu (Rady Ministrów) i organu kierującego określonym działem administracji rządowej, zwanego resortem ${ }^{32}$. Na podstawie art. 191 u.g.n. minister infrastruktury i budownictwa nadaje uprawnienia zawodowe w zakresie szacowania nieruchomości osobom fizycznym, które spełniły wymogi określone w przywoływanym już art. 177 u.g.n. Może natomiast odmówić nadania takich uprawnień osobom, które nie spełniają tych warunków. Należy też zauważyć, że procedura nadawania uprawnień ma charakter postępowania administracyjnego i kończy się wydaniem decyzji administracyjnej. Biorąc pod uwagę treść art. 191 u.g.n., trzeba przyjąć, że decyzja ta będzie miała charakter decyzji związanej ${ }^{33}$. Przepis ten nie ustanawia bowiem możliwości nadania uprawnień. Przewiduje natomiast, że w przypadku spełnienia przez osobę fizyczną ustawowych wymogów minister wydaje decyzję o określonej treści, w której nadaje uprawnienia zawodowe. Należy również podkreślić, że wydanie takiej decyzji poprzedzone jest postępowaniem kwalifikacyjnym, mającym na celu stwierdzenie, czy osoba fizyczna spełnia wymogi określone w art. 177 u.g.n. Postępowanie to przeprowadzane jest przez Państwową Komisję Kwalifikacyjną, powoływaną przez ministra infrastruktury i budownictwa.

Charakter tego postepowania budzi niestety pewne kontrowersje, ponieważ w doktrynie zaprezentowano zarówno poglądy, zgodnie z którymi jest to postępowanie administracyjne, jak i poglądy odmienne ${ }^{34}$. Wydaje się jednak, że bardziej trafne jest pierwsze stanowisko, ponieważ postępowanie kwalifikacyjne wplecione jest w postępowanie administracyjne toczące się przed ministrem, który kończy sprawę, wydając stosowną decyzję administracyjną. Szczegółowe przepisy regulujące sposób i tryb przeprowadzania postępowania kwalifikacyjnego, sposób ustalania i rodzaje kosztów tego postępowania, organizację Państwowej Komisji Kwalifikacyjnej oraz regulamin jej działania określa rozporządzenie Ministra Infrastruktury i Rozwoju w sprawie nadawania uprawnień zawodowych w zakresie szacowania nieruchomości ${ }^{35}$.

Pomimo iż w aktualnym stanie prawnym uprawnienia zawodowe rzeczoznawcy majątkowego nadawane są $\mathrm{w}$ toku postepowania kończącego się decyzją ministra, należałoby się zastanowić, czy kompetencja ta nie powinna przysługiwać

31 Obecnie minister infrastruktury i budownictwa; zob. http://mib.gov.pl/2-Jakzostacrzeczoznawcamajatkowym.htm (dostęp: 15.08.2017).

32 J. Boć, Prawo administracyjne, Wrocław 2010, s. 146, 154.

33 B. Adamiak, J. Borkowski, Postępowanie administracyjne i sqdowoadministracyjne, Warszawa 2011, s. 375.

34 E. Bończak-Kucharczyk, op. cit., komentarz do art. 191, pkt 3, s. 1262-1265.

35 Rozporządzenie Ministra Infrastruktury i Rozwoju z dnia 11 marca 2014 r. w sprawie nadawania uprawnień zawodowych w zakresie szacowania nieruchomości (Dz.U. z 2014 r. poz. 328). 
odpowiedniej korporacji zawodowej. Taka zmiana byłaby uzasadniona ze względu na szczególnych charakter zawodu rzeczoznawcy majątkowego, który ma cechy zawodu zaufania publicznego. Obecnie nie ma jednak samorządu zawodowego rzeczoznawców majątkowych, któremu można by przyznać taką kompetencję, ponieważ ustawodawca $\mathrm{w}$ dalszym ciągu nie zdecydował się na uchwalenie ustawy powołującej do życia taką korporację zawodową.

Co prawda w art. 17 ust. 1 Konstytucji przewidziano jedynie uprawnienie, a nie obowiązek ustanawiania samorządów zawodowych dla osób wykonujących zawody zaufania publicznego, jednakże warto się zastanowić, czy w niektórych sytuacjach ustawodawca nie powinien być zobligowany do skorzystania $\mathrm{z}$ tego uprawnienia. W tym miejscu można przywołać pogląd Waldemara Wołpiuka, który uważa, że swoboda ustawodawcy w zakresie tworzenia samorządów zawodowych może być ograniczona, gdy za istnieniem danej korporacji przemawiają „ustalone w Konstytucji zobowiązania ciążące na państwie”36. Taka interpretacja art. 17 ust. 1 Konstytucji mogłaby uzasadniać konieczność powołania do życia samorządu zawodowego rzeczoznawców majątkowych, albowiem wykonywane przez nich czynności zawodowe pomagają realizować ciążący na państwie konstytucyjny obowiązek ochrony prawa własności, ustanowiony w art. 21 ust. 1 Konstytucji ${ }^{37}$.

Ewentualne utworzenie korporacji zawodowej rzeczoznawców majątkowych mogłoby wiązać się z przekazaniem kompetencji do nadawania uprawnień zawodowych w zakresie szacowania nieruchomości właściwym organom samorządowym. Takie rozwiązanie odpowiadałoby dotychczasowej praktyce legislacyjnej w stosunku do innych zawodów zaufania publicznego, posiadających swój samorząd zawodowy. Przykładowo można tu wskazać art. 68 ust. 1 ustawy Prawo o adwokaturze $^{38}$, który przewiduje, że wpis osoby, która uzyskała pozytywny wynik z egzaminu adwokackiego, na listę adwokatów następuje na jej wniosek, na podstawie uchwały Okręgowej Rady Adwokackiej. Innym przykładem będzie art. 17 ust. 6 ustawy o biegłych rewidentach, firmach audytorskich oraz nadzorze publicznym $^{39}$, który stanowi, że uchwały o wpisie do rejestru biegłych rewidentów podejmuje Krajowa Rada Biegłych Rewidentów. Podobną regulację znajdziemy w art. 5 ust. 1 ustawy o zawodzie lekarza i lekarza dentysty ${ }^{40}$, który stanowi, że prawo wykonywania zawodu lekarza albo prawo wykonywania zawodu lekarza dentysty przyznaje Okręgowa Rada Lekarska ${ }^{41}$. Na podstawie powyższych przy-

36 W. Wołpiuk, Zawód zaufania publicznego z perspektywy prawa konstytucyjnego, [w:] Zawody zaufania publicznego..., s. 23.

37 Art. 21 ust. 1 Konstytucji: „Rzeczpospolita Polska chroni własność i prawo dziedziczenia”.

38 Tekst jedn. Dz.U. z 2016 r. poz. 1999.

39 Dz.U. z 2017 r. poz. 1089.

40 Tekst jedn. Dz.U. z 2017 r. poz. 125.

$41 \mathrm{~W}$ doktrynie pojawił się pogląd, zgodnie z którym prawo do wykonywania zawodu lekarza nie powstaje na mocy uchwały Okręgowej Rady Lekarskiej, ponieważ ma ona charakter dekla- 
kładów możemy zauważyć, że w przypadku profesji zaufania publicznego ustawodawca często przyznaje kompetencje do nadawania uprawnień zawodowych organom korporacji zawodowej.

Trzeba jednak podkreślić, że w wypadku niektórych zawodów zaufania publicznego kompetencję nadawania uprawnień zawodowych przyznano odpowiednim organom administracyjnym. Taka sytuacja występuje w przypadku notariuszy, których na mocy art. $10 \S 1$ ustawy Prawo o notariacie ${ }^{42}$ powołuje minister sprawiedliwości lub w przypadku rzeczników patentowych, którym zgodnie $\mathrm{z}$ art. 18 ustawy o rzecznikach patentowych ${ }^{43}$ prawo do wykonywania zawodu przyznaje Prezes Urzędu Patentowego. Jednakże nawet w tych wypadkach korporacje zawodowe notariuszy i rzeczników patentowych mają pośredni wpływ na przyznawanie uprawnień zawodowych, albowiem od rozstrzygnięć ich organów zależy wpis na listę aplikantów notarialnych (art. $71 \S 3$ u.p.n.) i rzeczniowskich (art. $28 \mathrm{~b}$ ust. $1 \mathrm{w}$ Zw. $\mathrm{z}$ art. $51 \mathrm{a}$ ust. 1 pkt 3 u.r.p.).

Biorąc pod uwagę przywołane przepisy, przyznanie odpowiedniej korporacji zawodowej kompetencji do nadawania uprawnień zawodowych w zakresie szacowania nieruchomości byłoby uzasadnione. Alternatywnym rozwiązaniem mogłoby też być przyznanie takiemu samorządowi pośredniego wpływu na przyznawanie uprawnień zawodowych, jak uczyniono w przypadku zawodu notariusza i rzecznika patentowego.

\section{Wnioski}

Podsumowując powyższe rozważania, należy stwierdzić, że zawód rzeczoznawcy majątkowego z całą pewnością jest profesją o szczególnym charakterze. Mimo to nie można jednoznacznie określić jego statusu prawnego. Niewątpliwie zawód rzeczoznawcy majątkowego możemy zaliczyć do wolnych zawodów. Przemawiają za tym cechy profesji rzeczoznawcy oraz fakt zaliczenia jej do kategorii wolnych zawodów w art. 88 k.s.h. Nie ma natomiast pewności, czy zawód rzeczoznawcy majątkowego należałoby zaliczyć do zawodów zaufania publicznego, o których mowa w art. 17 ust. 1 Konstytucji. Po części wynika to z tego, iż ustrojodawca nie zdefiniował pojęcia „zawodu zaufania publicznego" i nie wskazał, które zawody mieszczą się w zakresie znaczeniowym tego pojęcia. Mimo to na podstawie poglądów doktryny i orzecznictwa ustalono pewne cechy takich profesji. Po przeanalizowaniu tych cech i zestawieniu ich z przepisami działu V ustawy o gospodarce nieruchomościami możemy dojść do wniosku, że zawód

ratoryjny. Zob. M. Nesterowicz, Nowe ustawodawstwo medyczne (osiagnięcia i błędy), „Państwo i Prawo" 1997, z. 9, s. 11-12.

42 Tekst jedn. Dz.U. z 2016 r. poz. 1796; dalej: u.p.n.

43 Tekst jedn. Dz.U. z 2017 r. poz. 1314; dalej: u.r.p. 
rzeczoznawcy majątkowego mógłby zostać zaliczony do kategorii zawodów zaufania publicznego.

Ustalenie tego faktu jest istotne dla oceny regulacji dotyczącej nadawania uprawnień w zakresie szacowania nieruchomości. Obecnie kompetencja do nadawania tych uprawnień przysługuje ministrowi właściwemu do spraw budownictwa, planowania i zagospodarowania przestrzennego oraz mieszkalnictwa. Jednak w przypadku zawodów zaufania publicznego ustawodawca często przyznaje kompetencje do nadawania uprawnień zawodowych odpowiednim organom samorządów zawodowych, utworzonych na podstawie art. 17 ust. 1 Konstytucji.

W związku z powyższym wydaje się, że ustawodawca powinien skorzystać ze swojej konstytucyjnej kompetencji i utworzyć samorząd zawodowy rzeczoznawców majątkowych, a także przyznać jego organom możliwość nadawania uprawnień zawodowych $\mathrm{w}$ zakresie szacowania nieruchomości. Za przyjęciem takich regulacji mógłby przemawiać szczególny status prawny zawodu rzeczoznawcy majątkowego oraz chęć dostosowania obecnych przepisów ustawy o gospodarce nieruchomościami do regulacji obejmujących nadawanie uprawnień zawodowych przedstawicielom innych zawodów zaufania publicznego.

\section{Empowerment in terms of the real estate evaluation}

\section{Summary}

In Polish jurisprudence we can distinguish two specific groups of professions: the liberal professions and the professions of public trust. The profession of the real estate appraiser for sure may be ranked as a liberal profession. Nevertheless, there is no certainty if this profession may be ranked as a profession of public trust. Qualification of the real estate appraisers to this second group of professions could be a reason to justify a change of the existing regulation concerning empowerment in terms of the real estate evaluation. Therefore there is a need to determine the legal status of the real estate appraiser profession and to judge the regulations which concern empowerment in terms of real estate evaluation.

Keywords: liberal profession, profession of public trust, profession self-government, real estate evaluation, real estate appraiser. 